\title{
INCREASING TREND OF BRAND CONSUMPTION AND ITS EFFECTS ON YOUTH'S SOCIAL IDENTITY
}

\author{
Abd ul Waheed $^{1 *}$, Umme Kalsoom ${ }^{2}$, Iqra Almas ${ }^{3}$, Sehrish Batool ${ }^{4}$, Muhammad Afzal Sadaf ${ }^{5}$ \\ ${ }^{1 *}$ Associate Lecturer, Department of Sociology, The Islamia University of Bahawalpur, Pakistan; ${ }^{2}$ M.Phil., Scholar, \\ Department of Sociology, University of Sargodha, Pakistan; ${ }^{3}$ Associate Lecturer, Department of Sociology, The Islamia \\ University of Bahawalpur, Pakistan; ${ }^{4}$ Lecturer, Cadet College for Girls, Chakwal, Pakistan; ${ }^{5} \mathrm{Ph} . D$., Scholar, Department \\ of Political Science, The Islamia University of Bahawalpur, Pakistan. \\ Email: ${ }^{1 *}$ raiwaheed772@yahoo.com, ${ }^{2}$ ummekalsoom369@gmail.com, ${ }^{3}$ iqraalmas40@gmail.com, \\ ${ }^{4}$ sehrishbatool006@gmail.com, 5 sadaf_hrl@yahoo.com \\ Article History: Received on $26^{\text {th }}$ May 2021, Revised on $4^{\text {th }}$ June 2021, Published on $8^{\text {th }}$ June 2021
}

\begin{abstract}
Purpose of the Study: The present research examined the effects of brand consumption on the social identity of youth.

Methodology: In this study, the researcher used a quantitative research approach; and survey research method was used, the questionnaire was used as a tool of data collection. A sample of 385 students was chosen by using a convenient sampling technique. In this study, researchers used SPSS for data analysis.

Principal Findings: The findings show that brand consumption has a positive relationship with social identity. Major findings show that brand consumption has negative relation with the overall well-being of respondents. Findings also show that the main purchased item was apparel brands.
\end{abstract}

Applications of the study: This study can be helpful in better understanding of youth's attitude towards brands consumption and its effects on their social identity.

Novelty/Originality of this study: People make their choices every day and consumer studies seek to know these choices. Differentiating brand consumption as a real phenomenon, this research aims to examine the increasing trend of brand consumption and its effects on youth's social identity. Despite of the increasing demand for luxury brand products in the modern era, a few types of research have been concluded to find out the link between luxury brands consumption and youth social identity. To better understand the brand consumption's effect on youth's social identity; this research inspected the social identity of youth in details.

Keywords: Brands, Trend, Consumption, Youth, Identity, Consumer, Luxury.

\section{INTRODUCTION}

People in the post-modern era are threatened by many different problems of their own such as helplessness, Division, lack of complexity and fight against acceptance. These problems are due to the terrible fear of not having a preserve identity. However, people are scared by the high occupation, because it goes out to eliminate options and replace them. Youth has many options, they can buy anything which they want due to the availability of multiple options. The suggestions for vendors to think about consumers identity that is important to understand the notion and power of self, examples of goods, and the role which the brands play (Gabriel and Lang, 1995, p98).

In the postmodern era, it is necessary to understand that the consumers make different choices according to products criteria and also from their representative values. The roles of the symbolic good of goods work in two ways: the first one is outward to make the social system, interaction with people, human well-being; and inward to make our own identity, self-representation (Elliott, 1997). Consumption plays a very important role in the maintenance of consumer personal, social interaction, and social media; it gives meaning and value to goods, so advertising is considered to be the most important part of these representatives' meaning. (McCracken, 1988; Mick \& Buhl, 1992).

Various age groups of individuals have various preferences for the brands. Young individuals have gone crazy in the context of the brands. They often go for the brand's products such as apparel, shoes, and many others. To look unique and stylish they are ready to spend a huge amount. Despite this youth is crazy for brands products. The young people of Pakistan are particularly not the same as their ancestors and they do not adhere to indistinguishable things from their forerunners. In fact, they are more advance in their field of studies, yet in different hobbies, they are associated with. It is generally excellent to see that by spending somewhat more cash, the youth of the middle class does appear to be unique. Brand awareness and consciousness has expanded the world in generally and among the young people of Pakistan particularly. The expansion in this pattern has given rise to depression among the adolescent as well, that is not good at all. Various driving issues which have been broken down in light of brand awareness are self-question, reduction of basic leadership possibilities, incomparable ascent in depression in early adolescence, feeling of social vulnerability, overstated level of copying others, and sometimes enthusiastic unevenness. (Ahmed, H.M., et al 2013). Distinguishing brand consumption as a real phenomenon, this research aims to recognize the association between social identity and brand consumption. Despite the increasing demand for luxury brand products in the modern era, very little researches have been completed to find out the link between brands consumption and social identity. To develop a better understanding of brand consumption's link with the social identity of youth, this study would help in this context. 


\section{The motivation of the study}

In this paper, the reader would get to know the addiction of societal people toward the brand's consumption. They only think that the adoption of high-end products with good brand tags could represent them Nobel and acceptable in front of other people. And they indulged themselves in the race of luxuries brand adoption. It is seen that the practice of consumption of high quality and branded products was present in the bake eras of kings and queens. So that they look different and symbolize themselves in the sense of highness. So the people adopt the brands to meet the symbolic identity which is only dependent on the brand in this current age. In this study, researchers have spent much time analysing available information and organising their ideas. Researchers also desire to do creative work to get respectability.

\section{RESEARCH OBJECTIVE}

The main objective of this research is to investigate the relationship between social identity and brand consumption.

\section{REVIEW OF LITERATURE}

One of the important variables in consumer researches seems as uniqueness. Primarily, the specific representation by an individual and the individuality of other people might be constructed by a specific area or country (Donnelly, 2016). Consumption and ownership of goods can convey symbolic means to its holder, that can be deliberately, or even unconsciously. Consumption is mostly a measure of social distinction, where people target to differentiate their social position (ibid). In earlier time people of the lower class were not allowed to wear brands products to become different from the higher class (Han, Nunes \& Dréze, 2010).

People with a good amount of income could buy the most expensive and good products. And this purely represents the high wish for the uniqueness of people (ibid). Some of them use the most luxury and good amount products they are very selective in the taste as they always prefer to be a unique person in front of people. Most of the former researchers have seen these types of practices was make by the duke and ditches of the empires in those old times. Nowadays peoples are facing competition and try to impress other people. Luxuries became the first and foremost priority for today's individuals (Giovannini, Xu \& Thomas, 2015).

People with brand anxiety used high-end products and wish to see their higher status in their society and in front of people. They contribute their addiction in the social cum political activities as well. This seems like an old practice where people used to adopt the branded products and polish their social worth. The experts gave their point of views and they said that people used to do the same practice to enhance their acceptance in the society and admire other people by their appearance. That's why the individuals have competition and they want to stay focused on buying the high-end products for consumption and show off purpose. (Correia, K.et al 2016).

After the age of modernism, it is recognised that people of today's world do not adopt products for their necessities but only for representational purpose (Gabriel and Lang et al., 1995). Products have both representative and functional meanings: externally it represents the choices of products by society's people (consumers) and measures the social status toward adopting those products. And internally it represents the specifications and functions of the products (Elliott, 1997). Production and supply of the products usually depend on the customer demand and carry the standard patterns toward the social world. (Mick \& Buhl et al., 1992).

After the age of modernism, the concept of self is not that who only adopts the trends of the society and its system. On the other hand, the postmodernism represents some specific activity or consumption of the products. The consumption of products roughly represents the choices of the consumers about what they want, it usually highlights the values of the society (

Thompson (1995) talks about the self as it important figure of society. And it must have to contribute to building up material projects. Which can represent the self and its cognitions into reality in the form of material production. Markus and Nurius (1986) recommend that a person can practice different version of him/herself by indulging in various social activities and the role of media can also influence the social, cultural, and historical background of the descriptions and representations of the variety of versions of self.

Therefore, the concept of self is way different and difficult; the user of these products with tag names may have 02 types of selves. The first one is that he/she has the real one based on the facts and figures. On the other hand, the second one is that which he/she always idealised to be like that. In this era, everyone experience that we are living in the whole material world and over status and values depends on this pattern if a person has good status we admire him/her for only brands adopting reason. The process of socialization and brand adoption linked differently. They don't adopt that different variety of brands for the same look but they adopt them and compete with one another to look different and unique. Diversity and its promotion are only by adopting different material statuses by the people as they fixed and set it as the higher and lower statuses of the consumers. In other term, there is a difference between the desire for assets and accomplished belongings. Hence, this circumstance can add to the disappointment among materialists. Therefore the concept of self is way different and difficult (Belk et al., 1985). 
According to (Thorstein Veblen, 1899) people who have a good source of income and money in their bank accounts usually consume and buy good branded and expensive tag things. They used to get expensive treatments to maintain their high status in front of other people. According to (Elliot, 2005) Narrative identity theory; in past and present era's man usually should spread the identity and other people to interlink with the things that we can't show or tell the people by practice. Consequently, we have to show it by telling and narrating in the form of stories with their connection to that period and the regions.

According to (Woodruffe-Burton, 2005) by giving the simple and daily life connected lifestyle to people we can get rid of the complexities and confusions from the people. We can easily interlink the daily life routines and every event in so transparency. On the other hand, if we use to do advertisement of goods narratively and logically it will be helpful in the coordination of man and his needs.

If we do extend the identity of a single self and implement it all over then it would be considered as the collective selves' relatability. This representation refers to a complex connection between the lingual practice and adoption by its internal and external relationship (Hudders, L., 2013). There are seen many events related to the daily routine of the human beings of the society by which we can easily judge the needs and trends of the people, there is always seen a great struggle seen about their priorities and choices or wishes. The active conversation about the product specification and concession of the meaning of goods and services. According to (Caniato et al., 2012) luxury items are connected with a uniqueness that recommends an exceptional quality or a delightfully engaging plan, with uniqueness, which infers cost and shortage. Every society has its standards of good and bad. Trends are always set by a small group of people and then they spread to the whole society. (Dittmar,1992) concluded about the logical meanings of the products which a person use not only the representations of the material things. If anything is launched by the brand with a specific symbol it means that it wants to show and express the identity of that product toward the consumers. Moreover (McCracken,1988) talked about the formal and symbolic specifications of the products by the societal people. And show the relationship of the product not occasionally but a mutual interconnection of the people and his related set of norms and values.

Socialization is a process by which a person learns the symbols and how to identify the meaning attached to these symbols. It is observed that every person has not the same meaning for a specific product. A product has maybe more than one meaning that is understandable for producer and consumer according to their consciously need toward that good and the dependency of product based on the consumption by the societal peoples and their cultural practices (Ritson et al., 1996).

It is observed the consumption of goods and services by a consumer is not his/her own choice but it is a source to maintain the identity that a person wants to be in front of society. (Belk, 1988). Luxury fashion products with high quality and expensive are a source of being unique, and being unique is a source of self-satisfaction for an individual.

The symbolic meaning associated with luxury products is the desire to impress others for one's class and social status. Now a day's luxury product defines the social status of individual who uses these products. The more expensive and high-quality products one carry the high social status he belongs to, traditionally social class and status is also defined by the goods and services that one holds, (Tsai 2005). Usage of the high-end and branded goods interlink with the higher ratio of their consumption (O'Cass and Frost, 2002).

It is usually thought and seen if a person use and buy good expensive things he/she symbolized the high status in the society. Most of the time social status of the people is measured. A wish to improve social status can be achieved by the conspicuous consumption of luxury brands products. There is a visible ratio about those consumers who are using branded products are considered so rich in society, but some of them are just dreaming to adopt that type of luxuries. According to (Levine, 1997) a lot of buyers "would slightly have a Rolex than a household".

The outer and calculated ratio of the consumers of good can relate to the people who have that material identity and they feel good to announce as their personality which can appeal to people towards them. There is the main difference of the class system which depends on the cultural adoption and luxuries life or poor life. However, there are so many flaws that can differentiate them in the politeness or rudeness in their behaviour (De, 1998).

Now a day, the spreading of money and time for the sake of the luxury life and this practice is usually seen in the general people as well not only the wealthy ones. Nowadays the access to luxuries is way easy and there is seen great competition between the super-rich and upper rich classes so they want to meet more social acceptability and nobility by the adoption of these brands. Kravets and Sandikci (2014) said that the people of the society are well-educated and have sustainable economic conditions they could easily travel and they have a better sense of fashion and the updated trendy brands in the market places (p. 136).

In more addition, the luxuries goods have so much impact on the changing competition because there are a lot of brands offering a wide variety of products for their buyers. And there is a great struggle between the super-rich and upper-rich classes. They want a more prominent identity and acceptance in front of the societal people as they are so much conscious about their high status. (Eastman \& Liu, 2012).

In the 1990s the branded and luxurious products have been introduced in the marketplace. It became the symbol to show off the high economical condition and they became the specific a rich-class of people in the society (Vigneron \& 
Johnson, 2004). In further addition, the lack of jobs and low salaries also affect the buying and using those luxuries and expensive products by the middle-class people. It is the vital cause of self-specification. And by this trend, it had been made the source of the showing-off in front of people of the society (Truong et al., 2008). So there are the chances that a specific group of people can afford those luxuries and have the opportunity to be prominent in society (ibid).

Branded goods have a wider range and everyone can access them so easily and the quality and quantity adjustment and the diversity of the different buyers and groups to use their branded goods (Truong et al., 2008). Now several people are using the branded and high-end products (ibid). At the same time, most of the experts have their views about brand consumption that it is the way to decrease the social gaps of the classes (Dogan et al., 2018). It seems like the differentiation of the classes is becoming less day by day. Brands are motivating more people to adopt their products, and it is not only for the super-rich and upper-rich classes only (ibid). The people who have Two social identities are better than those who have only one identity, similarly, those who have three identities are better than those who have only two identities, and so on. Constant with this thinking, there is no significant proof for the additive health and wellbeing special effects of a growing number of social identities in a variety of surroundings. (Steffens, Haslam, et al., $\underline{2016)}$.

Nowadays, Groups also use most of their time functioning towards specific collective results this not only channels their focus and efforts (Hopkins et al.,2016) but also provides them with a sense of collectiveness (Reicher, 2016). Significantly, these positive effects of several group memberships on well-being are only perceived to the degree that the social identities in question are harmonious, positive, and significant for the people in defining themselves (Cruwys, et al.,2016). Social identities show who we are in real, also provide us with meaning, aim, and belonging, identities also provide us a significant psychological platform on which to stand (Greenaway et al., 2016).

\section{HYPOTHESIS}

To achieving the research objective the following hypothesis is formulated.

$\mathrm{H}_{01}$ : Brand consumption has a significant association with social identity.

\section{Conceptual Framework}

\section{INDEPENDENT VARIABLE DEPENDENT VARIABLE}

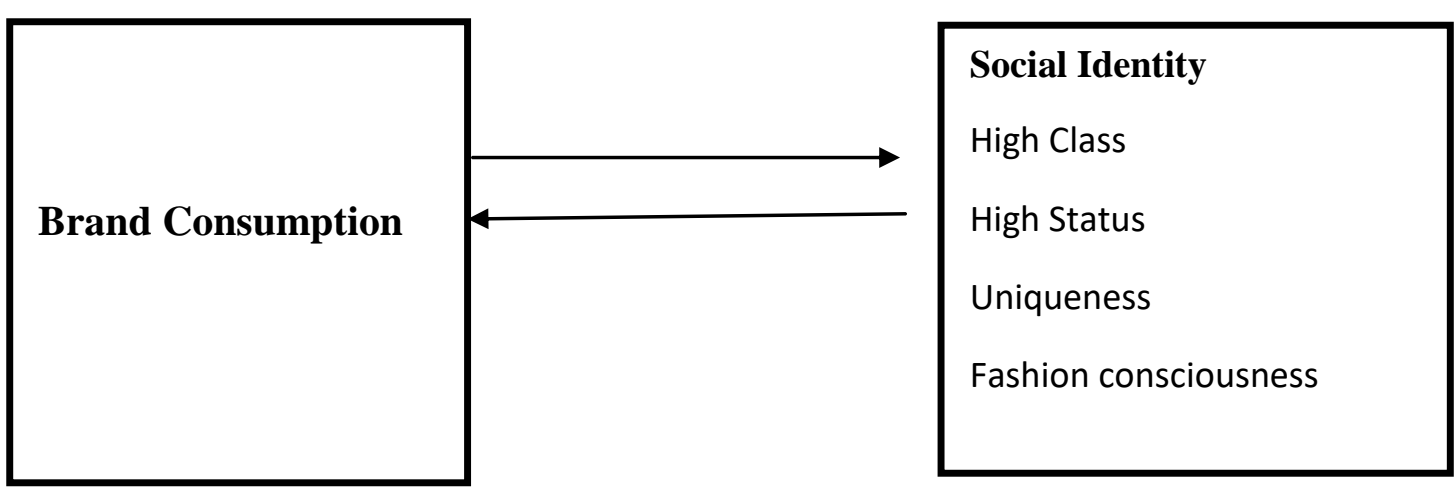

BACKGROUND VARIABLE

\section{Demographic Variable}

Gender

Education

Institution

Family Income

Figure 1: Indicators of social identity and demographic variables

\section{RESEARCH METHODOLOGY}

It was a quantitative study; by using the questionnaire increasing trend of brand consumption and its effects on youth's social identity was examined. The universe of this research was four. Universities were the University of Punjab, Bahauddin Zakriya University Multan, University of Sargodha, and Quaid e Azam University Islamabad. These Universities were selected through purposive sampling and different faculties of universities were selected conveniently. 
By using Convenient sampling data were collected by students. The questions were shaped on the Likert scale, interval options, and yes or no options. Data was analyzed on "SPSS" software.

\section{Sampling}

The total population under this research is shown in table 1.

Table 1: Total population

\begin{tabular}{lll}
\hline Sr. No & Universities & Registered Students \\
\hline 1 & Punjab University & 45000 \\
\hline 2 & Bahauddin Zakariya University & 35000 \\
\hline 3 & University of Sargodha & 28342 \\
\hline 4 & Quaid-i-Azam University & 13000 \\
\hline & Total & 121342 \\
\hline
\end{tabular}

\section{Sampling Technique}

Raosoft sampling calculator has been used.

The total sample of this research was set up equal to " 385 ".

For obtaining the desired sample the "proportional allocation method was used".

$$
\left(n_{i}=\frac{\mathrm{N}_{\mathrm{h}}}{N} \times \mathrm{n}\right)
$$

Where

( $n_{i}=$ Sample distributed in particular university).

$\left(\mathrm{N}_{\mathrm{h}}=\right.$ Number of registered students in particular university).

( $\mathrm{N}=$ Total number of registered students in all four universities).

$(\mathrm{n}=$ Total sample selected).

(Proportional Distribution of Sample in Punjab University)

$\left(n_{i}=45000 / 121342 * 385\right)$

$\left(n_{i}=142\right)$

(Proportional Distribution of Sample in BahauddinZakariya University)

$\left(n_{i}=35000 / 121342 * 385\right)$

$\left(n_{i}=111\right)$

(Proportional Distribution of Sample in University of Sargodha)

$\left(n_{i}=28342 / 121342 * 385\right)$

$\left(n_{i}=90\right)$

(Proportional Distribution of Sample in Quaid-i-Azam University)

$\left(n_{i}=13000 / 121342 * 385\right)$

$\left(n_{i}=42\right)$

Thus the university-wise distribution of the sample is given in table 2 .

Table 2: University wise distribution of sample

\begin{tabular}{lll}
\hline Sr. No & Universities & Sample selected \\
\hline 1 & Punjab University & 142 \\
\hline 2 & Bahauddin Zakariya University & 111 \\
\hline 3 & University of Sargodha & 90 \\
\hline 4 & Quaid-i-Azam University & 42 \\
\hline & Total & 385 \\
\hline
\end{tabular}




\section{Sample Framework}

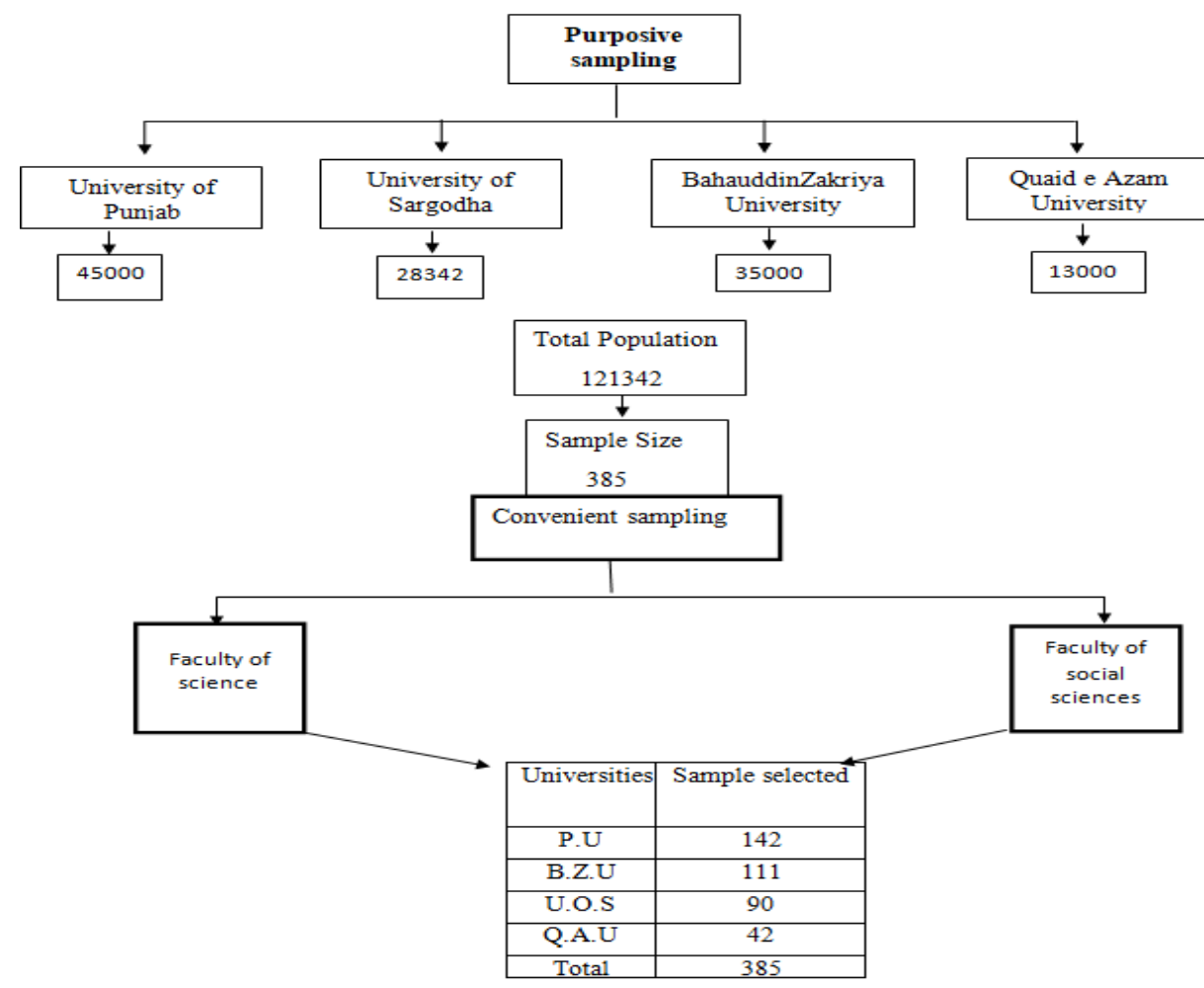

Figure 2: Sampling framework Tree

\section{RESULTS AND DISCUSSION}

Monthly Shopping items

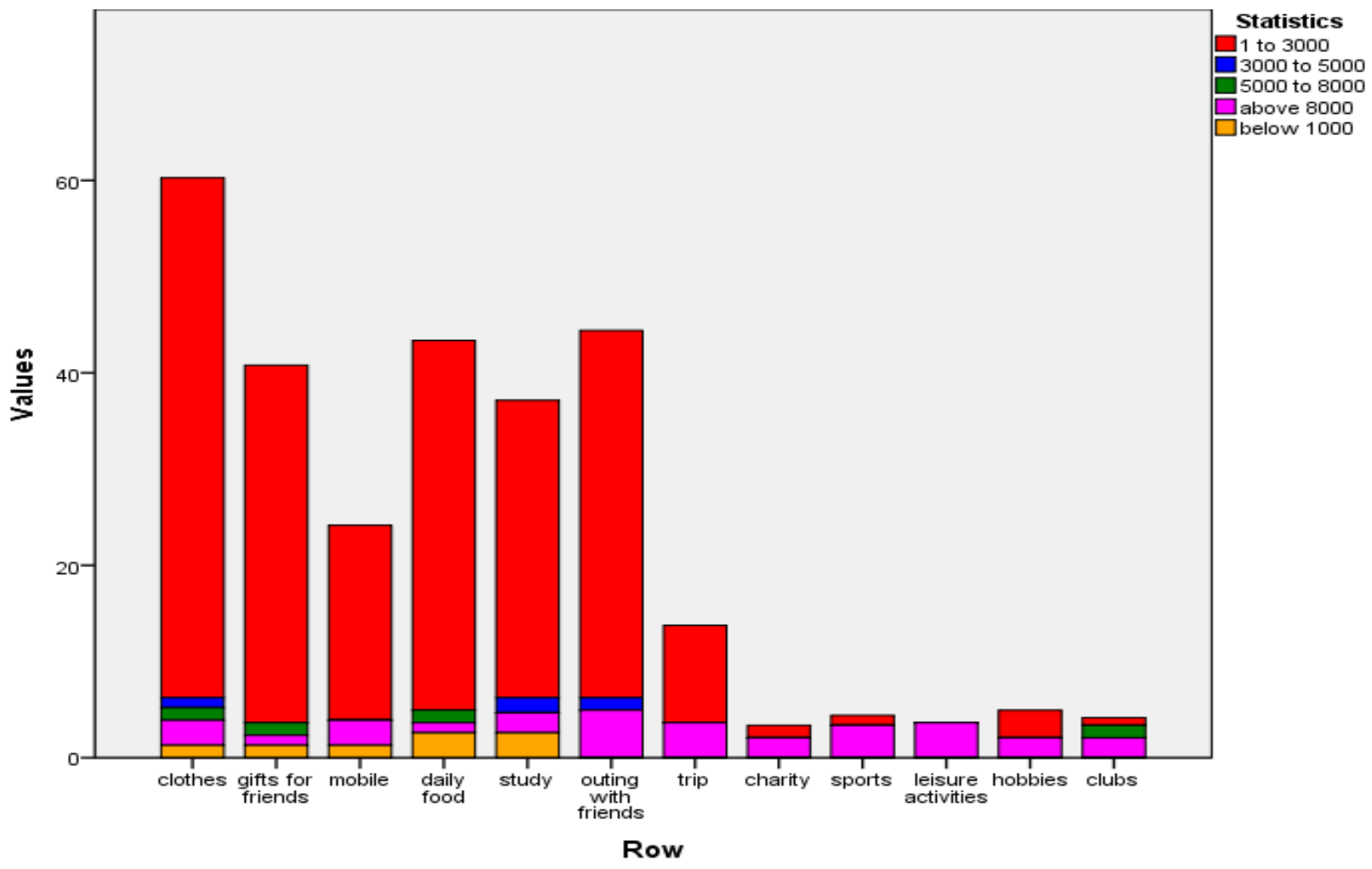

\section{Consumption Items}

Figure 3: A Graphical representation of Monthly Shopping Items 
This graph shows the frequency distribution of respondents according to "Monthly Shopping Items" in this graph respondents responds according to their monthly shopping items. This graph also shows categories of money which they spent on different items. The majority of respondents spent money on clothes, secondly on daily foods items, thirdly on an outing with friends. This graph is showing that the least percent of respondents spend money on charity, sports, leisure activities, hobbies, and in clubs.

\section{Social Identity}

Table 3: Measurement of social identity

\begin{tabular}{|c|c|c|c|c|c|}
\hline Scale & 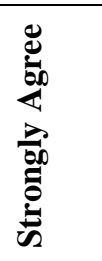 & 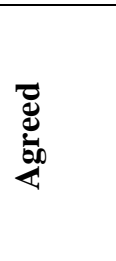 & Z & 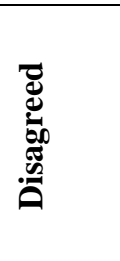 & 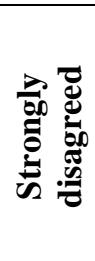 \\
\hline Wearing branded clothes is sign of popularity & $2.6 \%$ & $37.7 \%$ & $12.2 \%$ & $42.6 \%$ & $4.9 \%$ \\
\hline Wearing branded clothes is sign of high income & $1.3 \%$ & $50.6 \%$ & $5.5 \%$ & $38.7 \%$ & $3.9 \%$ \\
\hline Wearing branded clothes is sign of high class & $2.6 \%$ & $51.4 \%$ & $5.5 \%$ & $35.6 \%$ & $4.9 \%$ \\
\hline Wearing branded clothes is sign of high status & $1.3 \%$ & $45.3 \%$ & $16.6 \%$ & $31.8 \%$ & $5.0 \%$ \\
\hline Wearing branded clothes is sign of fashion consciousness & $1.3 \%$ & $47.3 \%$ & $12.2 \%$ & $35.6 \%$ & $3.6 \%$ \\
\hline Wearing branded clothes is sign of Uniqueness & $2.6 \%$ & $40.5 \%$ & $12.2 \%$ & $38.4 \%$ & $6.2 \%$ \\
\hline People become more respectable when they wear branded clothes & $0.0 \%$ & $33.0 \%$ & $15.3 \%$ & $44.4 \%$ & $7.3 \%$ \\
\hline
\end{tabular}

In this table, a social identity scale was used to determine social identity among respondents. In this table, respondents responded according to their social identity. This table shows values of every question like "Wearing branded clothes is a sign of popularity" majority of respondents i.e. (37.7) \% were agreed on this statement while $12.2 \%$ remained neutral and $42.6 \%$ have disagreed and only $4.9 \%$ were strongly agreed. This table further shows values of the statement "Wearing branded clothes is a sign of high income" majority of respondents i.e. (50.6) \% were agreed on this statement while $5.5 \%$ remained neutral and only $38.7 \%$ disagreed. This table further shows values of the statement "Wearing branded clothes is a sign of high class" majority of respondents i.e. (51.4) \% were agreed on this statement while 5.5\% remained neutral and only $35.6 \%$ have disagreed. This table further shows values of the statement "Wearing branded clothes is a sign of high status" majority of respondents i.e. (45.3)\% were agreed on this statement while $16.6 \%$ remained neutral and only $31.8 \%$ have disagreed. This table further shows values of the statement "Wearing branded clothes is a sign of fashion consciousness" majority of respondents i.e. (47.3) \% were agreed on this statement while $12.2 \%$ remained neutral and only $35.6 \%$ have disagreed. This table further shows values of the statement "Wearing branded clothes is a sign of Uniqueness" majority of respondents i.e. (40.5) \% were agreed on this statement while $12.2 \%$ remained neutral and only $38.4 \%$ disagreed. This table further shows the values of the statement "People become more respectable when they wear branded clothes" majority of respondents i.e. (44.4) \% have disagreed with this statement while $15.3 \%$ remained neutral and only $33.0 \%$ were agreed. Literature also indicates that one of the important variables in consumer researches was individuality. The individuality and the specification of a single person or the peoples of the society could be measured by the specifications and trend of that country or society. (Donnelly, 2016).

Consumption and ownership of branded goods could convey a specific representation toward the holder, that could see deliberately, intentionally or most of the time unintentionally. People adopt products by seeing others and they show a vital social representation and distinction, the main goal of the people is to change their class into the higher rank between the people (ibid). Consumption and ownership of branded goods could convey a specific representation toward the holder, that could see deliberately, intentionally or most of the time unintentionally. People adopt products by seeing others and they show a vital social representation and distinction, the main goal of the people is to change their class into the higher rank between the people (ibid). In earlier, it was prohibited for people from the working class to wear costly apparel items, to differentiate them from the elite class (Han et al., 2010). This table further shows that most respondents were agreed that wearing branded clothes is a sign of high class and wearing branded clothes is a sign of high income.

\section{Testing Hypothesis}

Table 4: Regression analysis of brand consumption and social identity

\begin{tabular}{llllll}
\hline \multirow{2}{*}{ Independent Variable } & \multicolumn{2}{l}{ Uns. Coefficient } & St. Coefficient & T & \multirow{2}{*}{$\boldsymbol{p}$} \\
\cline { 2 - 5 } & $\mathbf{B}$ & Std. Error & Beta & & \\
\hline Constant & 11.820 & 0.816 & & 14.481 & 0.000 \\
\hline Brand Consumption & 0.337 & 0.111 & 0.155 & 3.046 & 0.002 \\
\hline R & 0.155 & & & & \\
\hline Adj. R & 0.021 & & & & \\
\hline
\end{tabular}




\begin{tabular}{l}
0.024 \\
\hline $\mathrm{F}(1,378)=9.28, p=0.002$
\end{tabular}

This table comprised a regression analysis between brand consumption and social identity. The table revealed that brand consumption is positively related to social identity which means that a one-unit increase in brand consumption is increasing 0.337 units in social identity. The model is also fitted to the regression line as the $\mathrm{R}^{2}$ value $=0.024$ revealed it. This table shows that all values are positive, there is no value in negative. The researcher used a linear regression analysis test to find out the association between social identity and brand consumption of youth. The results demonstrate that there is a positive relationship between both variables. "Wearing branded clothes" is a sign of high income. "Wearing branded clothes is the symbol of high status", wearing apparel brands is the symbol of fashion consciousness, wearing branded clothes is the sign of high class in society. Therefore, in this context social identity is positively correlated with brand consumption. The people who wear branded clothes are considered; they have a high income. The people who wear apparel brands are considered; they belong to a higher class. By wearing branded clothes people are considered fashion conscious. Due to growing demands in the modern era of branded products the results show there is a positive relationship between brand consumption and the social identity of youth.

\section{Impact of brand consumption on well-being}

Table 5: Regression analysis of brand consumption and wellbeing

\begin{tabular}{|c|c|c|c|c|}
\hline \multicolumn{5}{|c|}{ Model Summary } \\
\hline Model & $\mathbf{R}$ & R Square & Adjusted R Square & Std. Error of the Estimate \\
\hline 1 & $.036^{\mathrm{a}}$ & .001 & -.001 & 8.747 \\
\hline
\end{tabular}

\begin{tabular}{|c|c|c|c|c|c|}
\hline \multicolumn{6}{|l|}{ Coefficients' } \\
\hline \multirow[t]{2}{*}{ Model } & Unstand: & d Coefficients & Standardized Coefficients & $\mathbf{t}$ & Sig. \\
\hline & $\mathbf{B}$ & Std. Error & Beta & & \\
\hline (Constant) & 60.796 & 1.421 & & 42.791 & .000 \\
\hline Brand consumption & -.136 & .192 & -.036 & -.706 & .481 \\
\hline
\end{tabular}

a. Dependent Variable: well-being

This table comprised linear regression analysis between brand consumption and overall well-being. The table showed that brand consumption is negatively related to well-being. Additionally, the results revealed that the "one-unit" rise in brand consumption reduces the 0.136 units in the well-being of students. Furthermore, though $\left(\mathrm{R}^{2}=0.001\right)$ is low, yet the model is meaningfully fitted on the "regression line".

\section{DISCUSSION}

The findings of this study show that majority of students did not agree that wearing branded clothes is a sign of popularity. It means that people don't think that wearing branded clothes can make them popular in society. Popularity is not dependent on branded clothes. Further mostly students disagreed that wearing branded clothes is a symbol of respect. This also shows that branded clothes do not affect the level of respect in society. This demonstrates that brand clothes are negatively related to people in society. While the majority was agreed that wearing brands is a sign of high class. This demonstrates that wearing brands is not a sign of popularity and respect in society instead it is a sign of high class. It's meant that the people who wear brands belong to the high class in society. Further, this study demonstrates that apparel brands are the symbol of uniqueness. The majority of students also agreed that apparel brands are the sign of high status. High status and high class are positively correlated with brand consumption, the people who wear branded clothes they are supposed to be of higher status. This study demonstrates that brand consumption has overall positive relation with social identity. In this context majority of students agreed that wearing branded clothes is the sign of fashion consciousness. It's meant that brand clothes have different designs which are according to modern era. Due to globalization world has become a global village. Different fashion designing companies make their products according to modern trending fashion, so the people who wear branded clothes are considered fashion conscious now a day. These findings show that wearing brand clothes has a direct link with the social identity of youth for instance; high status, high income, high class, uniqueness, and fashion consciousness.

Literature also indicates that one of the important variables in consumer researches was individuality. The individuality and the specification of a single person or the peoples of the society could be measured by the specifications and trends of that country or society. Identity of the consumer is in this context how a consumer uses social distinctive features to form their personality by the means of consumption, usually described by a set of norms for membership or estimated respond and work of the concerned societal people (Donnelly, 2016).

Consumption and ownership of branded goods could convey a specific representation toward the holder, that could see deliberately, intentionally or most of the time unintentionally. People adopt products by seeing others and they show a vital social representation and distinction, the main goal of the people is to change their class into the higher rank 
between the people (ibid). In earlier, it was prohibited for people from the working class to wear costly apparel items, to differentiate them from the elite class (Han et al., 2010). Consumption and ownership of branded goods could convey a specific representation toward the holder, that could see deliberately, intentionally or most of the time unintentionally. People adopt products by seeing others and they show a vital social representation and distinction, the main goal of the people is to change their class into the higher rank between the people (ibid).

\section{CONCLUSION}

The present study was conducted to find out the relation between brand consumption and the social identity of youth. The findings of the present study show that brand consumption has a positive relationship with the social identity of youth. Results of this research showed that the majority of students get 1000 to 5000 pocket money from home.

Participants in the present research indicated that most students occasionally go shopping. Most students buy shoes, mobile clothes, and cosmetics every month. It resulted in this study that most students prefer to use branded clothes. The majority of students agreed that they prefer branded clothes because of their qualities. The majority of students agreed that wearing branded clothes increases social acceptance among the peer group. It develops the social capital of the students and they know more about the world.

By this conclusion, the reader can easily get all the related clues and knowledge about the topic and discussed issue. In this paper, the writers tried to give more relevant accuracy and interlink all the main points in a sequence. In this study questionnaire is a tool for the collection of data. The universe was the students of the four universities (University of Punjab, Bahahuddin Zakrya University Multan, University of Sargodha, and Quaid e Azam University) through which the data were taken by using the method of convenient sampling. Data was analyzed by using the SPSS software. It is concluded that brand consumption has a positive relation with social identity because the majority of students were agreed that the choice of clothes reflects one's personality.

\section{LIMITATION AND STUDY FORWARD}

This study is restricted to only four Universities of Pakistan are, the University of Punjab, the University of Sargodha, Bahhuddin Zakraya University Multan, and Quaid EAzam University Islamabad. These are limitations because only four universities are selected for this research. These limitations will affect findings and conclusion because a few numbers of universities are selected purposively to examine the increasing trend of brand consumption and its effect on youth social identity.

\section{RECOMMENDATIONS}

Based on the outcomes of this study, brand consumption has positive effects on the social identity of youth; therefore, govt should promote and make better quality of local brands, thus we can promote our local culture as well as economy.

\section{AUTHORS' CONTRIBUTIONS:}

Abdul Waheed: Devise main idea, Research Methodology, Use of SPSS, Graphical representation, Discussion, Data Analysis and its interpretation, Abstract and Conclusion writing

Umme kalsoom: Writing the introduction and working on literature.

Iqra Almas: Data Collection, working on literature, writing references and after completion of research review the article

Sehrish Batool: Data Collection, working on literature, writing references, and after completion of research review the article.

Muhammad Afzal Sadaf: Data Collection, working on literature, writing references and after completion of research review the article and proofreading.

\section{REFERENCES}

1. Ahmad, W., Arshad, H. M., Sabir, R. I., \& Ashraf, R. U. (2013). Antecedents of purchase intention for foreign apparel products among Pakistani university students: Implications for market entry strategy. Middle-East Journal of Scientific Research, 16(9), 1255-1263.

2. Belk, R. W., 1985. Materialism: Trait aspects of living in the material world. Journal of Consumer Research, 12 (3), 265-280. . https://doi.org/10.1086/208515

3. Belk, R. W., Sherry Jr, J. F., \& Wallendorf, M. (1988). A naturalistic inquiry into buyer and seller behavior at a swap meet. Journal of Consumer Research, 14(4), 449-470. https://doi.org/10.1086/209128

4. Caniato, F., Caridi, M., Crippa, L., \& Moretto, A. (2012). Environmental sustainability in fashion supply chains: An exploratory case-based research. International journal of production economics, 135(2), 659-670. https://doi.org/10.1016/j.ijpe.2011.06.001

5. Correia, A., Kozak, M., \& Reis, H. (2016). Conspicuous consumption of the elite: Social and self-congruity in tourism choices. Journal of Travel Research, 55(6), 738-750. https://doi.org/10.1177/0047287514563337

6. Cruwys,T.,Haslam,S.A.,Dingle,G.A.,Haslam,C.,\&Jetten, J. (2014). Depression and social identity: An 
integrative review. Personality and Social Psychology Review, 18(3), 215-238. https://doi.org/10.11 77/1088868314523839

7. De Chernatony, L., \&Dall'Olmo Riley, F. (1998). Defining a" brand": Beyond the literature with experts' interpretations. Journal of Marketing Management, 14(5), 417-443. $\quad \underline{\text { https://doi.org/10.1 }}$ $\underline{362 / 026725798784867798}$

8. Dittmar, H. (1992). The Social P[Jchology of Material Possessions: To Have is To Be. Hemel Hempstead: Harvester Wheatsheaf.

9. Dogan, V., Ozkara, B. Y., \& Dogan, M. (2018). Luxury consumption tendency: conceptualization, scale development and validation. Current Psychology, 1-19.

10. Donnelly, M., \& Evans, C. (2016). Framing the geographies of higher education participation: Schools, place and national identity. British Educational Research Journal, 42(1), 74-92. https://doi.org/10.1002/berj.3196

11. Eastman, J. K., \& Liu, J. (2012). The impact of generational cohorts on status consumption: an exploratory look at generational cohort and demographics on status consumption. Journal of Consumer Marketing, 29(2), 93102.

12. Elliott, R. (1997). Existential consumption and irrational desire. European Journal of Marketing, 34(4), 285296.

13. Gabriel, Y. \& Lang, T. (1995). The Unmanageable Consumer: Contemporary Consumption and its Fragmentations. London: Sage Publications. http://dx.doi.org/10.4135/9781446213049.n6

14. Giovannini, S., Xu, Y., \& Thomas, J. (2015). Luxury fashion consumption and Generation Y consumers: Self, brand consciousness, and consumption motivations. Journal of Fashion Marketing and Management, 19(1), 2240.

15. Greenaway, K., Wright, R., Reynolds, K. J., Willingham, J., \& Haslam, S. A. (2015). Shared identity is key to effective communication. Personality and Social Psychology Bulletin, 41(2), 171-182. https://doi.org/10.1 177/0146167214559709

16. Han, Y. J., Nunes, J. C., \&Drèze, X. (2010). Signaling status with luxury goods: The role of brand prominence. Journal of marketing, 74(4), 15-30. https://doi.org/10.1509/jmkg.74.4.015

17. Hopkins, N., \& Reicher, S. (2016). The psychology of health and well-being in mass gatherings: A review and a research agenda. Journal of Epidemiology \& Global Health. https://doi.org/10.1016/j.jegh.2015.06.001

18. Hudders, L., Pandelaere, M., \&Vyncke, P. (2013). Consumer meaning-making: The meaning of luxury brands in a democratised luxury world. International Journal of Market Research,55(3), 391-412. https://doi.org/10.2501/IJMR-2013-036

19. Kravets, O., \&Sandikci, O. (2014). Competently Ordinary: New middle-class consumers in the emerging markets. Journal of Marketing, 78(4), 125-140. https://doi.org/10.1509/jm.12.0190

20. Levine, R. S. (1997). Martin Delany, Frederick Douglass, and the politics of representative identity. Univ of North Carolina Press. https://books.google.com.pk

21. Markus, H. \& Nurius, P. (1986). Possible selves. American Psychologist, 41 (9), 954-969. https://doi.org/10. 1037/0003-066X.41.9.954

22. McCracken, G. (1988). Culture and Consumption: New Approaches to the Symbolic Character if Consumer Goods and Activities. Bloomington: Indiana University Press. https://doi.org/10.1177/009207039101900209

23. McCracken, G. (1993). The value of the brand: an anthropological perspective. In Brand Equity and Advertising, (Ed.) Aaker, D. \& Biel, A. Hillsdale, NJ: Lawrence Erlbaum Associates. https://doi.org/10.1 77/205157071002500201

24. Mick, D.G. \& Buhl, C. (1992). A meaning-based model of advertising experiences. Journal of Consumer Research, 19, 317-338. https://doi.org/10.1086/209305

25. O'cass, A., \& Frost, H. (2002). Status brands: examining the effects of non-product-related brand associations on the status and conspicuous consumption. Journal of product \& brand management. https://doi.org/1 $\underline{0.1108 / 10610420210423455}$

26. Reicher, S. D., Haslam, S. A., \& Hopkins, N. (2005). Social identity and the dynamics of leadership: Leaders and followers as collaborative agents in the transformation of social reality. The Leadership Quarterly, 16(4), 547-568.

27. Ritson, M., Elliott, R. \& Eccles, S. (1996). Reframing IKEA: commodity-signs, consumer creativity and the social/ self dialectic. Advances in Consumer Research, 23, 127-131.

28. Solomon, M.R. (1996). Consumer Behavior. Third edition. London: Prentice-Hall International (UK) Limited.

29. Steffens, N. K., Haslam, S. A., Schuh, S. C., Jetten, J., \& van Dick, R. (2016). A meta-analytic review of social identification and health in organizational contexts. Personality and Social Psychology Review, 21(4), 303-335. Advance online publication. https://doi.org/10.1177/1088868316656701

30. Thompson, J.B. (1995) The Media and Modernity: A Social Theory of the Media. Cambridge: Polity Press. https://doi.org/10.1080/08821127.1997.10731899

31. Truong, Y., Simmons, G., McColl, R., \& Kitchen, P. J. (2008). Status and conspicuousness-are they related? Strategic marketing implications for luxury brands. Journal of strategic marketing, 16(3), 189-203. https://doi.org/10.1080/09652540802117124

32. Tsai, S. P. (2005). Impact of personal orientation on luxury-brand purchase value: An international 
investigation. International Journal of Market Research,47(4), 427-452. https://doi.org/10.1177/1470 78530504700403

33. Veblen, T. (1899). 1934. The theory of the leisure class. https://doi.org/10.4324/9781315135373

34. Vigneron, F., \& Johnson, L. W. (2004). Measuring perceptions of brand luxury. Journal of brand management, 11(6), 484-506. https://doi.org/10.1057/palgrave.bm.2540194

35. Woodruffe-Burton, H., \& Elliott, R. (2005). Compensatory consumption and narrative identity theory. ACR North American Advances. 